\title{
ANALYSIS CLAIM BPJS REVIEW FROM COMPLETENESS OF MEDICAL RECORD DOCUMENTS AND ACCURACY DIAGNOSIS CODES IN RSUD. dr. ISKAK TULUNGAGUNG
}

\author{
SUKIATUN \\ Magister of Heath Study Programe of STIKes Surya Mitra Husada Kediri \\ kikisiswanto69@yahoo.co.id
}

\begin{abstract}
Hospitals to document incomplete information, it is possible that the diagnostic codes are also inaccurate and have an impact on the cost of health services. The inaccuracies of the diagnostic codes and the completeness of the medical record will affect data and report information that ultimately affects the patient. The objective of the research was to analyze the BPJS Claim in terms of Document Record and Document Diagnosis Accuracy at RSUD dr. Iskak Tulungagung. The research design used was observational analysis. The study population was All Medical Record Document Inpatient BPJS patients in RSUD dr. Iskak Tulungagung. The sample size ware 140 by using systematic random sampling technique. Independent variable of research is Document Record and Document Diagnosis Accuracy. The dependent variable was BPJS Claims. Data was collected using Check list, then the data were analyzed using logistic regression with a significance level of $\alpha \leq 0.05$. The result showed that have the most medical record documents are incomplete resume as many as $52,1 \%$, most have anaaccurate diagnosis code as much as 58,6\% and the majority of escape document claims after verification by BPJS officials as many as 78,6\%. Results logistic regression analysis obtained by vulue off overall statistics (p) 0,794, which means that documents medical records and the accuracy of diagnosis codes did not affect claims BPJS. There are several factors that make BPJS claims that are not all medical records are subject to BPJS claims, complete medical record documents but still require clarification, any diagnosis if the code may be included on the INA $C B G^{\prime}$ 's software and in certain cases a copy of the investigation, action and evidence of medical device is required.
\end{abstract}

Keywords: Medical Record, Accuracy Diagnosis Code, claims BPJS.

\section{INTRODUCTION}

The Word Health Organization (WHO) has brought together several countries in the world to agree on achieving Universal Health Coverage (UHC) in 2014. Law No. 40 of 2004 on the National Social Security System (SJSN) in Indonesia requires every citizen to have access to health services that is comprehensive and qualified to survive. One of the goals of the Millennium Development Goals (MDGs) is to target the achievement of health degrees throughout the world. One of the efforts made by the Indonesian government to improve health is by conducting a National Health Insurance (JKN) program per January 2014 through a Social Security Administering Agency (BPJS) (Rizki Oryza et al, 2015).
The Social Security Administering Body (BPJS) is the organizer of social security, so that when a person who has a financial crisis, whether due to entering the productive age, experiencing illness, having an accident, and even death, will be taken over by an institution that provides social security (Ulinuha, 2014). Promotive health care, preventive, curative and rehabilitative systems that are of high quality at the expense of society are very important. Law No. 40 of 2004 on the National Social Security System (SJSN) in Indonesia, answers the Universal Health Coverage Basic Principle by requiring every citizen to have access to comprehensive and quality health services in order to survive.

The government to improve the quality of health services, especially in 
terms of public health insurance, the government and related parties to form a new health insurance program that is the National Health Insurance. The goal is to meet the expectations of the community, each region must have health care facilities that can be accessed easily, through the hospital.

Hospital (RS) is a health service facility that can show the good service quality and right to society based on hospital standard so that it can fulfill the society expectation in health service. Implementation of health services can be measured from how to overcome health problems both medical and nonmedical. Hospitals should cooperate with relevant insurers, due to strong, stable, and sustainable health financing that plays an important role in the provision of health services. Regulation of the Minister of Health No. 27 of 2014 on the Technical Guidance of the Indonesian Case Base Group System (INA-CBGs) states that the payment pattern in the JKN program uses the Indonesian Case Base Group (INACBGs), using a prospective payment pattern in the form of clustering of diagnoses and procedures have clinical features and the use of similar resources (Permenkes No 27, 2014). Patients pay INA-CBG's tariff rates are affected by the rate from start to finish from a health service or hospital. The determination of the tariff to be issued can be seen from the completeness of the medical record file, because it contains various information about the patient who get service in the hospital. Hospitals that apply INA-CBGs become very important in making a complete and clear diagnosis based on ICD 10 and the accuracy of their diagnostic code (Idris, 2014).

Guidelines medical record service rumah pain in Indonesia (MOH, 2006) states that medical records are complete is a document medical records completed by physicians within $\leq 24$ hours after completion of service or as inpatients decided to return include the identity of the patient, anamnesis, care plans, implementation of care, follow-up and resume (Kurniawati, 2014). Complete medical records, providing information that can be used for various purposes. Such necessities are as evidence in lawsuit, research and education materials and can be used as a tool for analysis and evaluation on the quality of services provided by the hospital (Pamungkas, 2015). Hospitals in case of incomplete documentation of information, it is possible that the diagnosis codes are also inaccurate and affect the cost of health services. The inaccuracies of the diagnostic codes and the completeness of the medical record will affect data and report information that ultimately affects the patient. The current accuracy of INACBGs tariffs is currently used as a method of payment for patient services organized by BPJS. If the coding officer incorrectly assigns a diagnosis code, then the claim payment amount will also be different (Pramono, 2015).

The results of document medical record study at Muhamadiyah Malang University Hospital in 2016, from 40 medical records documents found that $100 \%$ not filled completely (Nurhaidah et al., 2016). The results showed that the completeness of information that has the highest complete value of $70 \%$, completeness of the lowest $30 \%$. The results also indicate that the complete and accurate information records document as much as $20 \%$, while the document records the complete information and inaccurate $10 \%$. Incomplete and accurate medical record document of $10 \%$, while incomplete and inaccurate 60\% (Pujihastuti, 2014).

The result of other research was found to fill the main diagnosis as much as $56,52 \%$ which was not fully filled, while the result of diagnosis was $81,01 \%$ accurate and $18,99 \%$ not accurate. The results of the research on the accuracy of diagnostic codes were obtained inaccurate 
diagnosis of diarrhea (30\%), DM (60\%), CHF (40\%), Dyspesia (30\%), CKD (65\%), and Abdominal Pain (10\%) (Saputri, 2015). The result of the research on medical record completeness found that incomplete filling of file of medical record of $40,43 \%$ of internal disease, patient identity data in $45,74 \%$ reviewed medical record file, incomplete of important report as much as $33,31 \%$ and 42 authentications, $55 \%$ (Pamungkas, 2010). The result of the research is found that obstetric diagnostic code is not accurate to BPJS claims that are not smooth as much as $66,7 \%$ and obstetric diagnostic code which is not correct to BPJS claim which is current as much as $33,3 \%$. However, obstetric diagnostic codes were found to be accurate against non-current BPJS claims of $17.6 \%$ and proper obstetric diagnostic codes against BPJS's current claim of $82.4 \%$ (Nurrul, 2014).

The result of analysis at Puskesmas Gondokusuman II of Yogyakarta city showed that the number of accurate code was $45,2 \%$ and not accurate $54,8 \%$ ) (Pramono, 2015). Data of 2015 in RSUD Banjarbaru got 97,17 encoding not accurate (Priyatama, 2015). Based on preliminary study at RSUD Dr. Iskak Tulungagung, in the fourth quarter of 2016 it was found that the average accuracy of the diagnostic code was $10.7 \%$ of inaccurate diagnosis codes and $80.3 \%$ accurate diagnostic codes. While on the item completeness of information completeness, there are $38.5 \%$ incomplete and 61.5 complete.

The completeness of the medical record document filling and the accuracy of the diagnosis code is very important. The medical record serves as a legal proof that every patient has and can be legally accountable. The medical record should be complete and clear about all services provided to the patient and also the accuracy of the diagnostic code. The incomplete factors of filling in the medical records of the disease are the limited time that doctors use to fill out the medical record file and the doctor's indiscriminately in filling out the medical record files. The incompleteness of the diagnosis or action codes and also the completeness of other medical records containing administrative data and medical data of the patient will have an impact on the financing process in the BPJS claim. One of the factors that influence the accuracy of the diagnosis code is the completeness of the medical information completeness and the accuracy of the code obtained by taking into account the information contained in the medical record document. Factors causing inaccuracies of other diagnostic codes include inappropriate human resource qualifications assigned to encode diagnoses, lack of Standard Operating Procedures (SOPs) for diagnostic coding, diagnostic data and codes in incomplete Puskesmas management information system (SIMPUS), and not optimal use book ICD-10 as a guide to diagnose the disease (Pramono, 2015).

The incompleteness of the medical record document and the accuracy of the diagnostic code is one of the problems as it is the only record that can provide detailed information about what has happened during hospitalization. This incompleteness impacts internally and externally because the result of data processing can be wrong because of the incompleteness. The results of reports based on the incompleteness of this data relating to the preparation of various hospital planning, decision-making by the manager especially the evaluation of services provided and expected results to be better. Impacts may arise inhibiting the process of insurance claims by a third party that is BPJS because the main diagnosis or accompanied by a secondary or additional diagnosis will be very influential with the amount of insurance claims filed. Another impact of the incomplete medical record and the accuracy of the diagnostic code is the obstruction of the administrative order, 
as the medical record document should have been in the Medical record installation but still returned to the responsible doctor for reinstatement. The quality of medical records is very important because it helps determine the quality of services available in hospitals (Pujihastuti, 2014)

The role of health managers in health services in hospitals becomes very important in order to complete the medical record and the accuracy of the diagnostic code so that BPJS claims can be accurate and correct. Managers in health services should be able to plan, monitor and evaluate so that the rotation of system improvement in the service continues to improve until the current dynamic conditions. The completeness of medical record documents and the accuracy of diagnostic codes is essential so that BPJS claims can be done well. Incompatibility between the completion of the medical resume completeness with the accuracy of the code on the patient's medical record sheet in RSUD Dr. Iskhak Tulungagung will be one cause of delayed claims BPJS. It may also be that the incompleteness of the medical record document or the inaccuracy of the diagnostic code but BPJS claims can be made, or vice versa where the complete medical record document as well as the diagnosis code is accurate but BPJS claims can not be made. BPJS officers and medical records play an important role in document control in the form of completeness as well as various factors to pass BPJS claims on every patient. Therefore, the researcher is interested to research about BPJS Claim in terms of Document Record and Document Diagnosis Accuracy in RSUD dr. Iskak Tulungagung.

\section{METHOD}

In general, this study aims to analyze BPJS Claim in terms of Medical Record Document and Accuracy Diagnosis Code in RSUD dr. Iskak Tulungagung.
Design research is a strategy to achieve the research objectives that have been established and used as a guide or guide researchers on the entire process of research. The research design used was observational analysis. The population of this research is All Document of Medical Record of patient of BPJS inpatient in dr. Iskak Tulungagung. The sample size was 140 using systematic random sampling technique. Independent Variable research is Medical Record Document Completeness and Accuracy Diagnosis Code. Dependent variable is Claim BPJS. Data were collected by using Chek list, then the data were analyzed using logistic regression test with significance level $\alpha \leq$ 0,05 .

\section{RESULTS \\ Distribution Characteristics of Respondens}

Table 1.Distribution Characteristics of Respondents based Document Addresses Patient Medical Record BPJS Inpatient in RSUD dr. Iskak Tulungagung April 2017

\begin{tabular}{|c|c|c|c|}
\hline No & Address & $\Sigma \mathbf{N}$ & $\Sigma \%$ \\
\hline 1 & Tulungagung & 116 & 82,9 \\
\hline 2 & Beyond Tulungagung & 24 & 17,1 \\
\hline & Total & 140 & 100 \\
\hline
\end{tabular}
number of respondents amounted to 140 Documents Record Medical patients BPJS hospitalized. Based on patient medical resume data as the table above shows that most respondents are domiciled in tulungagung as many as 116 respondents $(82.9 \%)$ and $24(17.1 \%)$ of respondents came from various regions outside Tulungagung.

Table 2. Distribution Characteristics of Respondents by Education Patient Medical Record Document BPJS Inpatient in RSUD dr. Iskak Tulungagung April 2017 


\begin{tabular}{clcc}
\hline No & Education & $\mathbf{\Sigma N}$ & $\mathbf{\Sigma \%}$ \\
\hline 1 & SD & 47 & 33,6 \\
2 & SMP & 26 & 18,6 \\
3 & SMA & 37 & 26,4 \\
4 & PT & 18 & 12,9 \\
5 & Lain-lain & 12 & 8,6 \\
\hline & Total & $\mathbf{1 4 0}$ & $\mathbf{1 0 0}$ \\
\hline
\end{tabular}

Based on the above table shows that the education level of respondents based on the Medical Record Documents of patients vary widely. Most respondents had elementary education as many as 47 respondents $(33.6 \%)$, then the next most high school 37 (26.4\%) and education respondents SMP 26 (18.6\%) ranks third.

Table 3. Distribution Characteristics of Respondents by Age Patient Medical Record Document BPJS Inpatient in RSUD dr. Iskak Tulungagung April 2017.

\begin{tabular}{clcc}
\hline No & Age (years old) & $\mathbf{\Sigma N}$ & $\mathbf{\Sigma \%}$ \\
\hline 1 & Toddler (0-5) & 5 & 3.6 \\
2 & Children (6-11) & 2 & 1.4 \\
3 & Early adolescents (12-16) & 4 & 2.9 \\
4 & Teenagers (17-25) & 7 & 5.0 \\
5 & Early adult (26-35) & 17 & 12.1 \\
6 & The final adult (36-45) & 12 & 8.6 \\
7 & Early elderly (46-55) & 30 & 21.4 \\
8 & Elderly (56-65) & 25 & 17.4 \\
9 & Seniors (> 65) & 38 & 27.1 \\
\hline \multicolumn{2}{r}{ Total } & $\mathbf{1 4 0}$ & $\mathbf{1 0 0}$ \\
\hline
\end{tabular}

Based on the age distribution of Respondents based on the patient's Medical Record Document, that the most aged $>65$ years were 38 respondents $(27.1 \%)$, the next age group of the elderly (46-55 years) was $30(21.4 \%)$. While the age group is the least is the age class chillhood (6 - 11 years) as much as 2 (1.4\%).

Table 4. Distribution Characteristics of Respondents by Gender Patient Medical Record Document BPJS Inpatient in RSUD dr. Iskak Tulungagung April 2017.

\begin{tabular}{clcc}
\hline No & Gender & $\mathbf{\Sigma N}$ & $\mathbf{\Sigma \%}$ \\
\hline 1 & Man & 71 & 50.7 \\
2 & Women & 69 & 49.3 \\
\hline & Total & $\mathbf{1 4 0}$ & $\mathbf{1 0 0}$ \\
\hline
\end{tabular}

The above table shows that the characteristics of respondents by sex Medical Record Document patients had at most respondent's male sex by 71 respondents $(50.7 \%)$ and $69(49.3 \%)$ were female.

Table 5. Distribution Characteristics by Marital Status Patient Medical Record Document BPJS Inpatient in RSUD dr. Iskak Tulungagung April 2017.

\begin{tabular}{clcc}
\hline No & Marital status & $\mathbf{\Sigma N}$ & $\mathbf{\Sigma \%}$ \\
\hline 1 & Married & 119 & 85 \\
2 & Single & 21 & 15 \\
\hline & Total & $\mathbf{1 4 0}$ & $\mathbf{1 0 0}$ \\
\hline
\end{tabular}

The distribution of respondent's marital status characteristics based on the patient's Medical Record Document as shown above shows that based on marital status, most of the respondents have married status of $119(85 \%)$ and $21(15 \%)$ have not married status.

Table 6 Distribution Characteristics of Religion Respondents based Patient Medical Record Document BPJS Inpatient in RSUD dr. Iskak Tulungagung April 2017.

\begin{tabular}{clcc}
\hline No & Religion & $\mathbf{\Sigma N}$ & $\mathbf{\Sigma \%}$ \\
\hline 1 & Islam & 139 & 99.3 \\
2 & Catholic & 1 & 0.7 \\
\hline & Total & $\mathbf{1 4 0}$ & $\mathbf{1 0 0}$ \\
\hline
\end{tabular}

The above table shows that the characteristics of respondents based Religion Data Refresh patient medical record, respondents mostly Muslim as much as 139 respondents $(99.3 \%)$ and a small Catholic $1(0.7 \%)$.

Table 7. Distribution of Respondents by Job Characteristics Patient Medical Record Document BPJS 
Inpatient in RSUD dr. Iskak Tulungagung April 2017.

\begin{tabular}{clcc}
\hline No & Work & $\mathbf{\Sigma N}$ & $\mathbf{\Sigma \%}$ \\
\hline 1 & Civil servants & 13 & 9.3 \\
2 & TNI / Polri & 1 & 0.7 \\
3 & Entrepreneur & 46 & 32.9 \\
4 & Etc & 80 & 57.1 \\
\hline & Total & $\mathbf{1 4 0}$ & $\mathbf{1 0 0}$ \\
\hline
\end{tabular}

Distribution Characteristics of Respondents job based document patient medical record as the table above shows that over $50 \%$ of respondents have a diverse work or other things that as many as 80 respondents $(57.1 \%)$, including: not working, a housewife, not school and pensioners. While $32.9 \%$ are selfemployed.

\section{Custom Data}

This research consists of 3 (three) variables that are two independent variables and one dependent variable. The third variable is the completeness of the documents referred to medical records of patients BPJS hospitalization, primary diagnosis code accuracy and claims BPJS. The result of the research shows the distribution of data from the three variables as illustrated in the table below.

\section{Document Record Completeness}

Table 8. Distribution Frequency Completeness Charging Document Patient Medical Record BPJS in RSUD dr. Iskak Tulungagung April 2017.

\begin{tabular}{clcc}
\hline No & $\begin{array}{c}\text { Document } \\
\text { Record } \\
\text { Completeness }\end{array}$ & $\mathbf{\Sigma N}$ & $\mathbf{\Sigma \%}$ \\
\hline 1 & Complete & 67 & 47.9 \\
2 & Incomplete & 73 & 52.1 \\
\hline & Total & $\mathbf{1 4 0}$ & $\mathbf{1 0 0}$ \\
\hline
\end{tabular}

The results of the investigation, as the table above in the variable documents of medical records found that most have sufficient documentation is incomplete medical resumes berk as many as 73 $(52.1 \%)$ of 140 files and 67 (47.9\%) had a complete medical resume complete.

Table 9. Frequency Distribution of Incomplete Filling of Document Medical Doctor Patient BPJS in RSUD dr. Iskak Tulungagung April 2017.

\begin{tabular}{clcc}
\hline No & $\begin{array}{l}\text { Medical Resume } \\
\text { Entry }\end{array}$ & $\mathbf{\Sigma N}$ & $\mathbf{\Sigma \%}$ \\
\hline 1 & Medical Indication & 33 & 45.2 \\
2 & $\begin{array}{l}\text { Follow-Up } \\
\text { Treatment }\end{array}$ & 24 & 32.9 \\
3 & Treatment & 6 & 8.2 \\
4 & $\begin{array}{l}\text { Doctor's name and } \\
\text { signature, hour }\end{array}$ & 6 & 8.2 \\
5 & $\begin{array}{l}\text { Sign Diagnosis } \\
6\end{array}$ & 2 & 2.75 \\
$\quad \begin{array}{l}\text { Summary of results } \\
\text { of investigation }\end{array}$ & 2 & 2.75 \\
\hline \multicolumn{2}{c}{ Total } & $\mathbf{7 3}$ & $\mathbf{1 0 0}$ \\
\hline
\end{tabular}

Of the 140 medical records of patients BPJS document hospitalization as mentioned above table 8 that $73(52.1 \%)$ file, its contents were not complete. The lack of medical resumes charging accessories can be seen in table 9, stating that occurred on the patient's medical indication sign which amounted to $45.2 \%$, $32.9 \%$ follow up care, treatment, doctor's name and signature as well as service hours respectively $8.2 \%$.

\section{Accuracy of Diagnostic Code}

Table 10. Accuracy Frequency

Distribution Code the Top

Diagnose Patient Medical

Record Document BPJS

Inpatient in RSUD dr. Iskak Tulungagung April 2017

\begin{tabular}{|c|c|c|c|}
\hline No & $\begin{array}{ll}\text { Accuracy } & \text { of } \\
\text { Diagnostic Code } & \end{array}$ & $\mathbf{\Sigma N}$ & $\Sigma \%$ \\
\hline 1 & Accurate & 82 & 58.6 \\
\hline 2 & Not accurate & 58 & 41.1 \\
\hline & Total & 140 & 100 \\
\hline
\end{tabular}

The results of the research on the variable of accuracy of the main diagnostic code on the medical record document of 
PBJS patient of Inpatient found that most had accurate diagnosis code as much as 82 respondents $(58.6 \%)$, while the inaccurate were 58 respondents $(41.1 \%)$. The inaccuracy of this diagnostic code occurs because of a misdiagnosis of 4 (four) characters in $33(56.9 \%)$ and miss-coded numeric characters of 25 documents $(43.1 \%)$. In detail can be seen in the table below.

Table 11. Inaccuracy Frequency Distribution Code the Top Diagnoses on Patient Medical Record Document BPJS Inpatient in RSUD dr. Iskak Tulungagung April 2017.

\begin{tabular}{llcc}
\hline $\mathbf{N}$ & $\begin{array}{l}\text { Inaccuracy of the } \\
\text { o }\end{array}$ & $\mathbf{\Sigma N}$ & $\mathbf{\Sigma \%}$ \\
\hline 1 & $\begin{array}{l}\text { Incorrect diagnostic } \\
\text { code on the fourth } \\
\text { character }\end{array}$ & 33 & 56.9 \\
2 & $\begin{array}{l}\text { Incorrect diagnostic } \\
\text { code on numeric } \\
\text { characters }\end{array}$ & 25 & 43.1 \\
\hline$\quad$ Total & $\mathbf{5 8}$ & $\mathbf{1 0 0}$ \\
\hline
\end{tabular}

Table 12. Frequency distribution of comorbid diagnoses on Patient Medical Record Document BPJS Inpatient in RSUD dr. Iskak Tulungagung April 2017.

\begin{tabular}{llcc}
\hline No & Description & $\mathbf{\Sigma N}$ & $\mathbf{\Sigma \%}$ \\
\hline 1 & No comorbid & 105 & 75.0 \\
2 & There comorbid & 35 & 25.0 \\
\hline & Total & $\mathbf{1 4 0}$ & $\mathbf{1 0 0}$ \\
\hline
\end{tabular}

Based on the patient's medical record document BPJS 140 hospitalizations a file after the observations are $105(75.0 \%)$ had no comorbid diagnosis obtained or comorbidities and 35 (25.0\%) obtained comorbid diagnosis.

Table 13. Frequency Distribution of Medical Measures in Patients BPJS Inpatient based Patient Medical
Record Document BPJS Inpatient in RSUD dr. Iskak Tulungagung April 2017.

\begin{tabular}{llcc}
\hline No & Description & $\mathbf{\Sigma N}$ & $\mathbf{\Sigma \%}$ \\
\hline 1 & $\begin{array}{l}\text { No Medical } \\
\text { Actions } \\
2\end{array}$ & 81 & 57.9 \\
$\begin{array}{l}\text { Medical } \\
\text { Actions exist }\end{array}$ & 59 & 42.1 \\
\hline & Total & $\mathbf{1 4 0}$ & $\mathbf{1 0 0}$ \\
\hline
\end{tabular}

The above table show that the medical record documents that have been made observations of 140 files obtained no medical procedure is performed on patients BPJS hospitalization due to illness and no medical treatment because of illness. No medical action was performed on the patient because the disease was 81 (57.9\%) and medical treatment was performed on the patient's inpatient BPJS because the disease was $459(2.1 \%)$.

\section{Claim BPJS}

Table 14. Patient Claims Frequency Distribution Based BPJS right Inpatient Patient Medical Record Document BPJS in RSUD dr. Iskak Tulungagung April 201.

\begin{tabular}{clcc}
\hline No & Claim BPJS & $\mathbf{\Sigma N}$ & $\mathbf{\Sigma \%}$ \\
\hline 1 & $\begin{array}{l}\text { Escaped } \\
\text { Claim }\end{array}$ & 110 & 78.6 \\
\hline 2 & $\begin{array}{l}\text { Claim } \\
\text { pending }\end{array}$ & 30 & 21.4 \\
\hline & Total & $\mathbf{1 4 0}$ & $\mathbf{1 0 0}$ \\
\hline
\end{tabular}

The result of the miscellany bell BPJS Claims found that most of escapes file claims after verification by officers BPJS as many as 110 files (78.6\%), whereas that was not lost as many as 30 file claims $(21.4 \%)$.

Table 15.Crosstab between Claim BPJS and Completeness of Medical Records Document Patients 
Inpatient PBJS in RSUD dr. Iskak Tulungagung April 2017.

\begin{tabular}{ccccc}
\hline \multirow{2}{*}{$\begin{array}{c}\text { Claim } \\
\text { BPJS }\end{array}$} & \multicolumn{4}{c}{$\begin{array}{c}\text { Completeness of Medical } \\
\text { Record Document }\end{array}$} \\
\cline { 2 - 5 } & \multicolumn{2}{c}{ Complete } & \multicolumn{3}{c}{ Incomplete } \\
\cline { 2 - 5 } & $\mathrm{n}$ & $\%$ & $\mathrm{n}$ & $\%$ \\
\hline $\begin{array}{l}\text { Escaped } \\
\text { Claim }\end{array}$ & 51 & 36,45 & 59 & 42,1 \\
\hline $\begin{array}{l}\text { Claim } \\
\text { pending }\end{array}$ & 16 & 11,45 & 14 & 10,0 \\
\hline Total & $\mathbf{6 7}$ & $\mathbf{4 7 , 9}$ & $\mathbf{7 3}$ & $\mathbf{5 2 , 1}$ \\
\hline
\end{tabular}

The results showed that most respondents has medical record documents are not complete yet escaped BPJS claim as many as 59 files $(42.1 \%)$. The results also show that there are $16(11.45 \%)$ respondents with complete medical record documents but BPJS claims are pending.

Table 16. Crosstab between BPJS and accuracy Claim Code PBJS Diagnosis in Patients Hospitalization in RSUD dr. Iskak Tulungagung April 2017.

\begin{tabular}{lcccc}
\hline \multirow{2}{*}{$\begin{array}{c}\text { Claim } \\
\text { BPJS }\end{array}$} & \multicolumn{2}{c}{ Accuracy of Diagnostic Code } \\
\cline { 2 - 5 } & \multicolumn{2}{c}{ curate } & \multicolumn{2}{c}{ Not accurate } \\
\cline { 2 - 5 } & $\mathrm{n}$ & $\%$ & $\mathrm{n}$ & $\%$ \\
\hline $\begin{array}{l}\text { Escaped } \\
\text { Claim }\end{array}$ & 64 & 45,7 & 46 & 32,8 \\
\hline $\begin{array}{l}\text { Claim } \\
\text { pending }\end{array}$ & 18 & 12,8 & 12 & 8,5 \\
\hline Total & $\mathbf{8 2}$ & $\mathbf{5 8 , 6}$ & $\mathbf{5 8}$ & $\mathbf{4 1 , 3}$ \\
\hline
\end{tabular}

The results showed that most respondents had accuracy accurate code diagnosis by 64 respondents $(45.7 \%)$ and the escapes BPJS claim, but there are 18 respondents (12.8\%) who have an accurate diagnosis code yet its claims pending BPJS. The results also showed that there were $46(32.8 \%)$ of respondents with an inaccurate diagnosis codes and escaped BPJS claims, and 12 (8.5\%) with an inaccurate diagnosis codes pending claims.
Table 17. Test results of the logistic regression variable Completeness and Accuracy Document Medical Record Patient Diagnosis Code BPJS to Claim BPJS

Variables in the Equation
\begin{tabular}{|l|r|r|r|r|r|r|}
\hline & B & S.E. & Wald & df & Sig. & $\operatorname{Exp}(\mathrm{B})$ \\
\hline $\begin{array}{l}\text { Step Constant } \\
0\end{array}$ & - &, 206 & 39,792 & 1 &, 000 &, 273 \\
\hline
\end{tabular}

\begin{tabular}{|c|c|c|c|}
\hline & Score & $\mathrm{df}$ & Sig. \\
\hline Step Variables Keakuratan_Dx(1) &, 032 & 1 & , 858 \\
\hline Kelengkapan_RM(1) & ,459 & 1 & ,498 \\
\hline Overall Statistics & ,461 & 2 & ,794 \\
\hline
\end{tabular}

Statistical test in this new study used logistic regression, test results listed in the table above. The results of statistical tests in this study showed that the variables in the equation obtained indigo slope or coefficients Beta (B) of the constants (Exp (B) of 0.273 , use values of significance $p$ value of Wald test of 0.000 , which means that each variable give partial effect. Value $\mathrm{B}$ is identical to the beta coefficient on ordinary least squares (OLS) with Exp $(1,299)=0.273$, which means that the independent variable has a positive effect by $27,3 \%$ to the dependent variable. Statistical test results obtained total df is 2 (two) which tells us the number of independent variables there are 2 (two).

Statistical test results the next stage in the second table shows that $\mathrm{p}>\mathrm{A}$ with a value of $<0.05$, as seen in the Overall Statistics with a significance value of (p) 0,794 , which means that no claim BPJS variables that affect both the documents and the accuracy of medical record Diagnosis Code. When viewed the value (p) on each free variable that is the accuracy of the diagnose code has a value (p) of 0.858 and variable completeness medical resume document value (p) of 0.498 . 


\section{DISCUSSION}

The results based on statistical test results showed that the variable document in the medical record completeness and accuracy of diagnosis codes to claim BPJS have a positive effect of $27.3 \%$.

Statistical test results showed that the next phase $p>A$ with a value of Overall Statistics with a significance value of (p) 0,794, which means that no claim BPJS variables that affect both the documents and the accuracy of medical record Diagnosis Code. When viewed the value $(p)$ on each free variable that is the accuracy of the diagnose code has a value (p) of 0.858 and variable completeness medical resume document value (p) of 0.498 .

The results obtained that no variables affect BPJS claims whether the completeness of medical record documents or the accuracy of the diagnostic code. This is supported by the results of research indicating that most respondents have incomplete medical record documents but pass BPJS claims as much as $42.1 \%$ of respondents, $11.45 \%$ respondent with complete medical record documents but BPJS claims are pending, 12, $8 \%$ of respondents had accurate diagnostic codes but their BPJS claims were delayed and $32.8 \%$ responded with inaccurate diagnostic codes and passed BPJS claims.

Other studies, on the Relationship Accuracy Diagnosis Code Obstetrics against Smoothness Claim BPJS in hospitals Saweigading Palopo South Sulawesi showed that obstetric diagnosis code is incorrect to claim BPJS is not smooth as much as $66.7 \%$ and obstetric diagnosis code that is not appropriate to claim BPJS which is as smooth as $33.3 \%$. It has been found appropriate obstetric diagnosis code to claim BPJS noncurrent $17.6 \%$ and obstetric diagnosis code is right to claim that current BPJS $82.4 \%$ (Nurul, 2014).

Inaccuracy or inaccuracy of coding diagnoses in medical records document will give show that may arise are delays in the process of insurance claims by third parties that is BPJS for writing the main diagnosis or accompanied by a secondary or additional diagnosis will be very influential with the amount of insurance claims filed. Another impact of the incomplete medical record and the accuracy of the diagnostic code is the obstruction of the administrative order, as the medical record document should have been in the Medical record installation but still returned to the responsible doctor for reinstatement. The quality of medical records is very important because it will determine the quality of existing services in hospitals (Pujihastuti, 2014).

When viewed from the benefits of the medical record that lists the values aspect known ALFREDS (Administrative, Legal, Financial, Research, Education, Documentation and Service), which is one aspect of its benefits is the financial aspect that the document in the medical record has a value of money, because it concerning data or information that can be used as financial aspect (MOH RI, 2006).

The financial aspects mentioned above in the era of BPJS is very important that the information in the medical record as the basic determinant of the tariff of BPJS known as INA CBG, $s$ is a payment system with the "package" system based on the illness suffered by the patient. The hospital will get a payment based on the tariff of INA CBG, s which is the average cost spent by a diagnosis group (Idris, 2014).

According to the researchers there are factors or other causes that make Claim pending BPJS claims. These factors are among others

Not all medical record content is a basic requirement of BPJS claims, there are some contents of the medical record that can be ignored at the time of claim file verification

Document complete medical record but still need clarification because their 
severity level that indicates the severity and magnitude of resulting in higher claims

Any diagnosis for existing code can be inserted in the CBG's INA software thus enabling tera iinaccuracies at the fourth character codes for diagnosis in the same group.

In some cases, copies of investigations are required, evidence of action and evidence of use of medical devices being grown even though the diagnostic codes are accurate.

Factors Claim pending will be useful for the evaluation of hospital management in following up and conducting an internal evaluation that includes the flow of medical records, the contents of the medical records, the requirements of the claim file, the claim file management, human resources and procedures for verification of the claim file. Evaluation needs to be done given the incompleteness of medical records and diagnosis codes internal and external impact because the processed data into the wrong lawyer. This data relates to the preparation of a variety of hospital planning, decision-making by managers in particular the evaluation of the service provided, and the expected results become better.

Implementation of good medical records will reflect the good quality service and will make it easier to meet the requirements BPJS claims so that the claims obtained in accordance with the resource $y$ ang spent in service delivery. This is not easy because many components are involved so that continuous monitoring of all lines is required.

\section{CONCLUSION}

Claim BPJS obtained the majority of files escaped claims after verification by BPJS officers as many as 110 files (78.6\%), while those who did not escape claims as many as 30 files $(21.4 \%)$.

The completeness of the medical resume document found that most had incomplete medical document resume of 73 files (52.1\%) of 140 files and 67 $(47.9 \%)$ had complete medical resume.

The accuracy of the main diagnostic codes on the patient's CVJS medical resume file was found to have the most accurate diagnostic code of 82 respondents $(58.6 \%)$, while the inaccurate were 58 respondents $(41.1 \%)$. The inaccuracy of this diagnostic code occurs because of a misdiagnosis of 4 (four) characters in $33(56.9 \%)$ and miss-coded numeric characters of 25 documents (43.1\%).

No variables that affect both documents claim BPJS medical record as well as the accuracy of diagnoses codes, with values signification of (p) 0.794 .

\section{REFERENCE}

Abdelhak M (2001) Health Information: Management Of A Strategic Resource 2nd Edition. Philadelphia: WB Sunders Company.

BPJS (2014a) Service Guide for BPJS Health Participants. BPJS Health.

BPJS (2014b) A Practical Guide to Health Services. BPJS Health.

Tulungagung Regional Development Planning Agency

Tulungagung In Figures.

MOH (2000) Training on the Use of the International Classification of Revision X (ICD-10). Jakarta: MOHRI Director General of Yanmed.

MOH (2006) Management Guidance of Medical Record Hospital at. Indonesia. Jakarta: DepKes RI Director General of YanMed.

Guwandi (2005) Medical Secrets. Jakarta: Faculty of Medicine, University of Indonesia. 
Hatta G (2009) Health Information Management Guideline In Service Facilities. Jakarta: Graha Ilmu.

Idris $F$ (2014) Changes in INA-CBGs Tariffs Make Costs More Effective. 6th ed. Jakarta: BPJS Health.

Ministry of Health (2008) no. 290 / MENKES / PER / III / 2008. Jakarta: Ministry of Health RI.

Kemenkes (2011) Handbook Socialization of National Health Insurance (JKN) in the National Social System. National health insurance. Jakarta: Ministry of Health RI.

Kemenkes (2013) Pocket Book FAQ (Frequently Asked Questions) BPJS Health. Jakarta: Ministry of Health RI.

Kresnowati L (2012) Module Action Classification II Morbidity Coding. Semarang.

Kurniawati (2014) Overview of Resume Out of Inpatient Outpatient Room Fourth Quarter at CIAMAM District Hospital. Indonesia, Journal of Health Information Management 2 (1): 26-31.

Lubis (2010) Introduction to Psychology in Nursing. Jakarta: Kencana Prenada Media Group.

No. 40 Law (2004) National Social Security System (SJSN) in Indonesia.

Nurhaidah, Harijanto $\mathrm{T}$ and Djauhari $\mathrm{T}$ (2016) Factors Causing the Incomplete Filling of Inpatient Medical Record at the University Hospital of Muhammadiyah Malang. Journal of Brawijaya Medicine 29 (3): $258-264$.

Nurrul AT (2014) The Correctness of Obstetric Diagnostic Code to Smoothness of BPJS Claim at Saweigading Hospital of Palopo
Municipality, South Sulawesi. Esa Superior University.

Nursalam (2008a) Concept and Method of Nursing Edition 2. Jakarta: EGC.

Nursalam (2008b) The concept and application of research methodology of nursing science. Jakarta: Salemba Medika.

Pamungkas (2010) Analysis of the Incomplete Filling of Medical Record File at PKU Muhammadiyah Hospital Yogyakarta. Journal of Public Health 4 (1).

Pamungkas (2015) Identification of Incompleteness of Medical Record Document Inpatient RSUD Ngudi Waluyo Wlingi. Jurnal Kesehatan Brawijaya 28 (2): 124-128.

Permenkes (2008) Regulation of the Minister of Health of the Republic of Indonesia Number 269 / Menkes / Per / III / 2008 About Medical Record. Jakarta: Minister of Health RI.

Minister of Health (2014) Regulation of the Minister of Health of the Republic of Indonesia Number 27 of 2014 Regarding Guidance System Base Case Indonesian Groups (INACBGs). Jakarta: Minister of Health RI.

Permenkes No 27 Act (2014) Technical Guidance of Indonesian Case Base Group (INA-CBGs) System. Jakarta: Minister of Health Regulation.

Pramono AE (2015) Accuracy of Disease Diagnosis Code Based on ICD-10 at Gondokusuman II Health Center Yogyakarta City. UGM.

Priyatama DA (2015) Review of Accuracy of Gastroenteritis Diagnostic Code in Inpatient Patients Based on ICD-10 and Laboratory Test Result in RSUD Banjarbaru in the third Quarter of 2013. Jurkessia 5 (3). 
Pujihastuti A (2014) Relation of Information Completion with Accuracy of Diagnosis and Action Code on Inpatient Medical Record Document. Indonesia Health Information Management Journal 3 (1).

Rustiyanto E (2009) Ethics Profession: Medical Record Health Information. Yogyakarta: Sudra.

Dr. Isaac Tulungagung (2014) Medical Record Implementation Guidelines revision 1.

Dr. Isaac Tulungagung (2016) Profile Regional General Hospital dr. Isaac Tulungagung.

Saputri ROF (2015) Identification Completeness and Accuracy of Information Document Code Medist Record Related Fees Rate Determination BPJS Patients in hospitals Pandan Arang Boyolali. Muhammadiyah University USrakarta.

Shofari B (2014) Management of Health Medical Record System. Semarang.

Sugiyono (2013) Quantitative Research Methods, Qualitative and R \& D. Bandung: Alfabeta.

Ulinuha FE (2014) Patient Satisfaction BPJS (Social Security Agency) Against Pelaanan Outpatient Unit (URJ) Permata Medika Hospital Semarang. Journal of KTI.. 